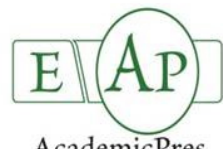

AcademicPres

\title{
Response of Durum Wheat Seedlings to Salinity
}

\author{
Mehmet YILDIRIM ${ }^{1}$, Ferhat KIZILGECI ${ }^{2}$, Cuma AKINCI ${ }^{1 *}$, Onder ALBAYRAK ${ }^{1}$ \\ ${ }^{I}$ University of Dicle, Faculty of Agriculture, Department of Field Crops, Diyarbakir, \\ Turkey;mehmety@dicle.edu.tr; akinci@dicle.edu.tr(*correspondingauthor);ondera@dicle.edu.tr \\ ${ }^{2}$ University of Sirnak, Faculty of Agriculture,Department of Field Crops, Sirnak, Turkey; ferhat_kizilgeci@hotmail.com
}

\begin{abstract}
Salinity is an important source of abiotic stress, limiting crop performance in most arid and semi-arid areas of the world. This research was conducted to determine the effects of salinity on physiological parameters of durum wheat (Triticum durum Desf.) genotypes. The research was conducted in the tissue culture laboratory at the Agriculture Faculty of Dicle University. The study consisted of one durum wheat commercial cultivar, five local cultivars and four advanced genotypes. There were three replications in a split-plot experimental design. Genotypes were germinated in four $\mathrm{NaCl}$ concentrations $(0,50,100,150 \mathrm{mM})$ in plastic boxes. There were statistically assured significant differences among the genotypes for all salt concentrations and all observed parameters (coleoptile length, seedling length, root length, seedling fresh weight, root fresh weight, seedling dry weight, root dry weight, germination rate and seedling vigor). There was significant decrease in all examined parameters depending on the increase of salt concentration. The 'Sorgul' genotype was most tolerant to salinity, in terms of root length and root dry weight, whereas 'Altintoprak 98' was most tolerant as measured by the impact of salinity on coleoptile length, seedling fresh weight, germination rate and seedling vigour. The 'Beyaziye' genotype was the most sensitive to salinity-induced stress. The results from this study demonstrated differences among durum wheat genotypes for seedling parameters measured in the presence of salinity stress.
\end{abstract}

Keywords: durum wheat, germination, physiological properties, salt tolerance, seedling

\section{Introduction}

Salinity is the accumulation of washed soluble salts into land water in arid and semi-arid areas. Evaporation of saline groundwater facilitates the salt to remain on the surface (Ekmekçi et al., 2005). Approximately 800 million hectares of global farmland are saline (FAO, 2008). Approximately 1.5 million hectares are saline or alkaline in Turkey (Dinç et al., 1993). Osmotic and ionic stress, induced in saline soils, is detrimental to plant growth and development (Parida and Das, 2005). Salinity can prevent the uptake of soil nutrients and harm plant structure by disturbing metabolic processes. Ionic stress affects plant growth by increasing $\mathrm{Na}^{+}$and $\mathrm{Cl}^{-}$levels in cells in response to high concentrations of $\mathrm{NaCl}$, and decreased $\mathrm{Ca}^{+}, \mathrm{K}^{+}$, and $\mathrm{Mg}^{+2}$ concentrations.

Wheat (Triticum aestivum L.) is an important source of energy and protein. Wheat acreage in Turkey is 8.1 million ha ${ }^{-1}$, producing an annual average of 20.1 million tons of grain and an average grain yield of $2.480 \mathrm{~kg} \mathrm{ha}^{-1}$ (FAO, 2013). Approximately $40 \%$ of the human daily energy requirement is provided by wheat products in Turkey (FAO, 2008). Production of wheat will need to increase to match the projected global population growth. Wheat has moderate tolerance to salinity stress (Shahzad et al., 2012), but grain yield is significantly reduced in soils containing over $100 \mathrm{mM} \mathrm{NaCl}$ or approximately $10 \mathrm{dS} / \mathrm{m}$ (Munns et al., 2006). Kanber and Unlu (2010) reported 50\% grain yield losses in wheat starting at $6 \mathrm{dS} / \mathrm{m}$. Compared to bread wheat, durum wheat (Triticum durum Desf.) is less tolerant of salinity due to a greater accumulation of $\mathrm{Na}^{+}$ions in the plant organs (Francois et al., 1986). Salinity tolerance has been shown to vary over wheat growth stages (El-Hendawy et al., 2005; Mass and Poss, 1989). With an increase in salt concentration, seedling fresh weight, root length, seed vigour and germination rate decreased (Ahmad et al., 2006; Akbari et al., 2007; Kizilgeci et al., 2010; Saboora and Kiarostami, 2006). Recognizing the high cost of developing cultivars tolerant to salinity, researchers have recently become more interested in screening plant species for this tolerance. Screening plant species for salinity tolerance or genetic potential to develop tolerance are considered highly promising approaches for developing salt tolerant commercial cultivars. Here, it was examined the response of 10 different durum wheat genotypes to 4 different salt concentrations, including control treatment, under laboratory conditions.

\section{Materials and methods}

The experiment was conducted on the tissue culture laboratory of the Agriculture Faculty of Dicle University, Diyarbakır, Turkey. The 10 durum wheat genotypes consisted of 1 commercial variety, 4 advanced lines and 5 local genotypes (Table 1). 
Table 1. Durum wheat genotypes used in the research

\begin{tabular}{|c|c|c|c|c|}
\hline \multirow{2}{*}{ Landraces Genotypes } & \multicolumn{2}{|c|}{ Commercial Cultivar } & \multicolumn{2}{|c|}{ Advanced Lines } \\
\hline & Name & Registered Institution & Name & Pedigri \\
\hline 'Bagacak' & 'Altintoprak 98' & GAPUTAEM & ‘Line 299’ & 'Gediz 75’ x 'Firat 93' \\
\hline 'Beyaziye’ & & & 'Line 286’ & ‘Gediz 75’ x 'Firat 93’ \\
\hline 'Menceki' & & & ‘6DZT21’ & 'Beyaziye’ x 'Bagacak' \\
\hline 'Mersiniye' & & & ‘6DZT29’ & 'Diyarbakir 81' x 'Firat 93' \\
\hline \multicolumn{5}{|l|}{ 'Sorgul' } \\
\hline${ }^{*}$ GAP International A & Research and Tra & ter & & \\
\hline
\end{tabular}

Table 2. Variance analysis and mean squares of the characteristics of some durum wheat genotypes grown in different salt concentration

\begin{tabular}{|c|c|c|c|c|c|c|c|}
\hline Parameters & Replic. & Salt Dose & Error $_{1}$ & Genotype & Salt x Genotype & Error $_{2}$ & C.V. \\
\hline Degree of freedom & 2 & 3 & 6 & 9 & 27 & 72 & \\
\hline Coleoptile length & 0.20 & $1.85^{* * *}$ & 0.02 & $1.15^{* * *}$ & 0.18 & 0.12 & 11.01 \\
\hline Seedling length & 0.43 & $144.29^{* * *}$ & 1.21 & $5.73^{* *}$ & $3.48^{* *}$ & 1.34 & 17.48 \\
\hline Root length & 3.97 & $42.23^{* * *}$ & 1.96 & $11.53^{* * *}$ & $5.42^{* *}$ & 1.88 & 22.62 \\
\hline Seedling fresh weight & 186.21 & $4913.29^{* * *}$ & 20.17 & $714.47^{* * *}$ & $159.53^{* *}$ & 78.95 & 17.76 \\
\hline Root fresh weight & $964.75^{* *}$ & $636.31^{*}$ & 178.12 & $586.44^{*}$ & 232.24 & 168.54 & 31.23 \\
\hline Seedling dry weight & 1.74 & $55.95^{* * *}$ & 0.21 & $12.67^{* * *}$ & 2.72 & 2.13 & 23.95 \\
\hline Root dry weight & $6.11^{* *}$ & $9.20^{* * *}$ & 1.42 & $2.59^{*}$ & 1.48 & 1.14 & 24.10 \\
\hline Germination rate & 28.23 & $6471.14^{* * *}$ & 140.67 & $1931.14^{* * *}$ & $174.80^{*}$ & 105.08 & 30.14 \\
\hline Seed vigor & 104.43 & $10926.79^{* * *}$ & 59.72 & $2174.31^{* * *}$ & $275.13^{* *}$ & 101.86 & 19.76 \\
\hline
\end{tabular}

Table 3. Average value of coleoptile length $(\mathrm{cm})$ of some durum wheat genotypes grown in different salt concentration

\begin{tabular}{lccccc}
\hline \multirow{2}{*}{ Genotypes } & \multicolumn{5}{c}{ Coleoptile Length $(\mathrm{cm})$} \\
\cline { 2 - 6 } & \multicolumn{5}{c}{ Salt Concentration (mM NaCl) } \\
\hline & 0 & 50 & 100 & 150 & Average \\
'Line 299' & 2.87 & 3.00 & 2.96 & 2.43 & $2.81^{\mathrm{de}}$ \\
'Line 286' & 2.94 & 3.42 & 3.34 & 2.96 & $3.17^{\mathrm{bc}}$ \\
'Altintoprak 98' & 2.82 & 3.11 & 3.21 & 2.45 & $2.02^{\mathrm{cd}}$ \\
'6DZT21' & 2.81 & 3.02 & 2.95 & $2.31^{\mathrm{de}}$ \\
'6DZT29' & 2.73 & 2.84 & 2.68 & $2.64^{\mathrm{e}}$ \\
'Mersiniye' & 3.01 & 3.14 & 3.61 & 2.83 & $3.16^{\mathrm{bc}}$ \\
'Menceki' & 4.09 & 4.09 & 3.17 & 3.39 & $3.68^{\mathrm{a}}$ \\
'Beyaziye' & 3.79 & 3.57 & 3.58 & 2.60 & $3.39^{\mathrm{b}}$ \\
'Sorgul' & 3.27 & 3.51 & 3.82 & 2.69 & $3.32^{\mathrm{bc}}$ \\
'Bagacak' & 3.19 & 3.40 & 3.16 & 2.91 & $3.17^{\mathrm{bc}}$ \\
Mean & $3.15^{\mathrm{a}}$ & $3.31^{\mathrm{a}}$ & $3.25^{\mathrm{a}}$ & $2.76^{\mathrm{b}}$ & \\
\hline
\end{tabular}

Infection risk was avoided by rinsing the wheat seeds with pure water after soaking them in 5\% Bleach solution $(\mathrm{NaOHCl})$ for $5 \mathrm{~min}$ at $20{ }^{\circ} \mathrm{C}$. For the germination experiment, $10 \mathrm{~cm}$ plastic Petri dishes and filter paper were used. The three $\mathrm{NaCl}$ concentrations were 50, 100, and 150 $\mathrm{mM}$. For each genotype, 25 seeds and $10 \mathrm{~mL}$ salt solution were placed in each Petri dish. The experiments were conducted in a germination room at $25^{\circ} \mathrm{C}$ for 7 days. An additional $5 \mathrm{~mL}$ saline solution was added to the Petri dishes during the fourth and fifth days. On the sixth day, $5 \mathrm{~mL}$ pure water were added to each dish.

The experimental design consisted of three replicates in a randomized split-plot design. The salt doses were main factor and genotypes were sub factor. The number of germinated seeds was recorded on the fourth day, and seedling vigour was recorded on the seventh day. Investigated properties which are germination rate, root size, seedling size, fresh root weight, and fresh seedling weight, were measured on the seventh day. The seedlings were then placed in an oven at $70{ }^{\circ} \mathrm{C}$ temperature for $48 \mathrm{~h}$ to measure dry root weight and dry seedling weight.

Analysis of variance was performed using the MSTAT-C statistic package. Means were compared according to Duncan's multiple range test.

\section{Results and discussions}

Analysis of variance results are presented in Table 2 . Significant differences were found between the genotypes over the three salt treatments and compared to the control. The genotype $\times$ salt treatment interaction was significant for seedling length, root length, seedling fresh weight, germination rate and seedling vigour.

Coleoptile length of the genotypes ranged from $2.64 \mathrm{~cm}$ to $3.68 \mathrm{~cm}$. For the three salt treatments, coleoptile length ranged from $2.76 \mathrm{~cm}$ to $3.31 \mathrm{~cm}$ (Table 3). Coleoptile lengths of all genotypes in the $50 \mathrm{mM}$ concentration were greater than coleoptile lengths of the control. Coleoptile lengths of 'Altintoprak 98' and 'Line 286' were greater than the control in each salt concentration, with an increase in length at the 150 $\mathrm{mM} \mathrm{NaCl}$ concentration. Coleoptile length of the 'Beyaziye' genotype was $31 \%$ shorter than that of the control. 'Beyaziye' was the genotype most susceptible to salinity. At the seedling growth stage, response to salt stress can be measured by changes in coleoptile length compared to the control. It can be therefore advised a shallow placement of seeds in salty soil when testing for tolerance.

Root length of the genotypes was from $3.85 \mathrm{~cm}$ to $7.23 \mathrm{~cm}$ and for different salt concentration treatments the averages were 
110

Table 4. Average value of root length $(\mathrm{cm})$ and seedling length $(\mathrm{cm})$ of some durum wheat genotypes grown in different salt concentration

\begin{tabular}{|c|c|c|c|c|c|c|c|c|c|c|}
\hline \multirow{3}{*}{ Genotypes } & \multicolumn{5}{|c|}{ Root Lenght $(\mathrm{cm})$} & \multicolumn{5}{|c|}{ Seedling Lenght $(\mathrm{cm})$} \\
\hline & \multicolumn{5}{|c|}{ Salt Concentration $(\mathrm{mM} \mathrm{NaCl})$} & \multicolumn{5}{|c|}{ Salt Concentration $(\mathrm{mM} \mathrm{NaCl})$} \\
\hline & 0 & 50 & 100 & 150 & Average & 0 & 50 & 100 & 150 & Average \\
\hline 'Line 299' & $8.62^{b c}$ & $8.41^{\mathrm{b}-\mathrm{d}}$ & $7.98^{b-f}$ & $3.92^{1-o}$ & $7.23^{\mathrm{a}}$ & $7.32^{\mathrm{d}-\mathrm{k}}$ & $6.55^{\mathrm{g}-\mathrm{m}}$ & $5.29^{\mathrm{k}-\mathrm{p}}$ & $2.96^{\mathrm{q}}$ & $5.53^{e}$ \\
\hline 'Line 286’ & $5.84^{\mathrm{d}-\mathrm{o}}$ & $6.31^{\mathrm{c}-\mathrm{n}}$ & $5.51^{\mathrm{e}-\mathrm{o}}$ & $4.78^{\mathrm{g}-\mathrm{o}}$ & $5.61^{c}$ & $9.62^{a-d}$ & $9.87^{\mathrm{a}-\mathrm{c}}$ & $7.83^{c-j}$ & $3.73^{o-q}$ & $7.76^{\mathrm{a}}$ \\
\hline 'Altintoprak 98' & $7.16^{\mathrm{b}-\mathrm{h}}$ & $8.13^{\mathrm{b}-\mathrm{e}}$ & $6.53^{\mathrm{cm}}$ & $4.42^{\mathrm{h}-\mathrm{o}}$ & $6.56^{\mathrm{abc}}$ & $7.43^{\mathrm{d}-\mathrm{k}}$ & $6.83^{e-1}$ & $7.63^{c-j}$ & $4.17^{\mathrm{n}-\mathrm{q}}$ & $6.52^{b-e}$ \\
\hline ‘6DZT21’ & $6.58^{\mathrm{c}-1}$ & $6.31^{\mathrm{c}-\mathrm{n}}$ & $6.77^{b-j}$ & $3.41^{\circ}$ & $5.77^{\mathrm{bc}}$ & $8.12^{\mathrm{ch}}$ & $8.44^{\mathrm{ch}}$ & $7.24^{\mathrm{e}-\mathrm{k}}$ & $3.73^{o-q}$ & $6.88^{a-c}$ \\
\hline ‘6DZT29’ & $9.37^{\mathrm{ab}}$ & $6.75^{b-j}$ & $7.44^{\mathrm{b}-\mathrm{g}}$ & $4.31^{\mathrm{i}-\mathrm{o}}$ & $6.97^{\mathrm{ab}}$ & $8.72^{b-g}$ & $6.63^{g-1}$ & $5.28^{\mathrm{k}-\mathrm{p}}$ & $3.30^{\mathrm{Pq}}$ & $5.98^{\mathrm{c}-\mathrm{e}}$ \\
\hline 'Mersiniye' & $5.28^{f-o}$ & $7.77^{\mathrm{b}-\mathrm{f}}$ & $5.83^{\mathrm{d}-\mathrm{o}}$ & $3.36^{\circ}$ & $5.56^{c}$ & $9.59^{\mathrm{a}-\mathrm{d}}$ & $7.84^{c-j}$ & $5.75^{\mathrm{j}-\mathrm{o}}$ & $3.92^{o-q}$ & $6.77^{\mathrm{a}-\mathrm{d}}$ \\
\hline 'Menceki' & $11.30^{\mathrm{a}}$ & $6.70^{\mathrm{b}-\mathrm{k}}$ & $4.43^{h-o}$ & $4.03^{j-o}$ & $6.60^{a b c}$ & $11.17^{\mathrm{a}}$ & $9.12^{\mathrm{a}-\mathrm{e}}$ & $3.91^{\mathrm{o}-\mathrm{q}}$ & $4.58^{\mathrm{l}-\mathrm{q}}$ & $7.19^{\mathrm{ab}}$ \\
\hline 'Beyaziye' & $3.60^{\text {no }}$ & $3.96^{\mathrm{k}-\mathrm{o}}$ & $3.77^{\mathrm{mo}}$ & $3.85^{1-o}$ & $3.85^{\mathrm{d}}$ & $10.68^{a b}$ & $7.99^{c-j}$ & $6.30^{h-n}$ & $3.18^{\mathrm{pq}}$ & $7.04^{\mathrm{a}-\mathrm{c}}$ \\
\hline 'Sorgul' & $6.07^{c-o}$ & $6.22^{\mathrm{c}-\mathrm{n}}$ & $6.91^{\mathrm{b}-\mathrm{i}}$ & $7.01^{b-i}$ & $6.56^{a b c}$ & $8.96^{b-f}$ & $8.07^{\mathrm{c}-\mathrm{i}}$ & $6.70^{f-1}$ & $3.83^{o-q}$ & $6.89^{a-c}$ \\
\hline 'Bagacak' & $7.40^{\mathrm{b}-\mathrm{g}}$ & $5.72^{\mathrm{d}-\mathrm{o}}$ & $5.91^{\mathrm{coo}}$ & $4.82^{\mathrm{g}-\mathrm{o}}$ & $5.96^{\mathrm{bc}}$ & $6.31^{\mathrm{h}-\mathrm{n}}$ & $6.66^{\mathrm{f}-1}$ & $5.79^{\mathrm{i}-\mathrm{o}}$ & $4.31^{\mathrm{m}-\mathrm{q}}$ & $5.77^{\mathrm{de}}$ \\
\hline Mean & $7.11^{\mathrm{a}}$ & $6.63^{\mathrm{ab}}$ & $6.11^{b}$ & $4.39^{c}$ & & $8.79^{a}$ & $7.80^{b}$ & $6.17^{c}$ & $3.77^{\mathrm{d}}$ & \\
\hline
\end{tabular}

Means followed by the same letter are not significantly different $(\mathrm{p}<0.05)$

Table 5. Average value of root fresh weight $(\mathrm{mg})$ and root dry weight $(\mathrm{mg})$ of some durum wheat genotypes grown in different salt concentration

\begin{tabular}{|c|c|c|c|c|c|c|c|c|c|c|c|}
\hline \multirow{3}{*}{ Genotypes } & \multicolumn{6}{|c|}{ Root Fresh Weight (mg) } & \multicolumn{5}{|c|}{ Root Dry Weight (mg) } \\
\hline & \multicolumn{6}{|c|}{ Salt Concentration $(\mathrm{mM} \mathrm{NaCl})$} & \multicolumn{5}{|c|}{ Salt Concentration $(\mathrm{mM} \mathrm{NaCl})$} \\
\hline & 0 & 50 & 100 & 150 & Average & & 0 & 50 & 100 & 150 & Average \\
\hline 'Line 299' & 45.97 & 53.96 & 39.90 & 23.86 & 40.92 & $\mathrm{ab}$ & 5.70 & 5.36 & 3.23 & 3.23 & $4.4^{\mathrm{abc}}$ \\
\hline ‘Line 286’ & 49.70 & 55.23 & 46.63 & 21.86 & 43.35 & ab & 5.93 & 5.76 & 5.93 & 3.60 & $5.3^{\mathrm{a}}$ \\
\hline 'Altintoprak 98' & 24.57 & 43.33 & 39.50 & 36.33 & 35.93 & b & 4.57 & 5.76 & 4.76 & 3.47 & $4.6^{\mathrm{abc}}$ \\
\hline ‘6DZT21’ & 42.37 & 46.56 & 45.76 & 31.73 & 41.60 & ab & 5.20 & 5.23 & 4.26 & 3.73 & $4.6^{\mathrm{abc}}$ \\
\hline ‘6DZT29’ & 54.93 & 51.30 & 40.73 & 34.26 & 45.30 & ab & 5.37 & 4.87 & 4.86 & 4.80 & $5.0^{\mathrm{ab}}$ \\
\hline 'Mersiniye' & 50.00 & 56.97 & 54.06 & 36.83 & 49.46 & a & 4.70 & 4.06 & 5.40 & 3.50 & $4.4^{\mathrm{abc}}$ \\
\hline 'Menceki’ & 53.90 & 49.17 & 29.73 & 51.93 & 46.18 & ab & 4.66 & 4.63 & 3.20 & 3.80 & $4.1 \mathrm{bc}$ \\
\hline 'Beyaziye' & 23.66 & 23.53 & 26.23 & 26.33 & 24.94 & c & 3.87 & 3.40 & 3.73 & 4.16 & $3.8^{c}$ \\
\hline 'Sorgul' & 28.90 & 38.76 & 49.30 & 46.83 & 40.95 & ab & 3.97 & 4.36 & 4.76 & 3.97 & $4.3^{b c}$ \\
\hline 'Bagacak' & 40.57 & 47.63 & 54.80 & 45.16 & 47.04 & ab & 4.43 & 4.33 & 4.86 & 2.13 & $3.9^{\mathrm{c}}$ \\
\hline Mean & $41.45^{\mathrm{ab}}$ & $46.64^{a}$ & $42.66^{a}$ & $35.51^{b}$ & & & $4.84^{\mathrm{a}}$ & $4.78^{a}$ & $4.50^{a}$ & $3.64^{b}$ & \\
\hline
\end{tabular}

Means followed by the same letter are not significantly different $(\mathrm{p}<0.05)$

between $4.39 \mathrm{~cm}$ and $7.11 \mathrm{~cm}$ (Table 4). Root length for salt treatments was less than for the control, and decreased with increasing salt concentrations. Previous studies also reported a decrease in root length with an increase in salt concentration (Akbarimoghaddam et al., 2011; Atak et al., 2006; Kumar et al., 1981). Root length of the 'Menceki' genotype decreased by 64\%, compared to the control, at the highest $\mathrm{NaCl}$ concentration. Root length is an important parameter when selecting for tolerance to salinity, as roots have direct contact with the soil and are responsible for accessing nutrients and water.

Seedling length of the genotypes averaged between $5.53 \mathrm{~cm}$ and $7.76 \mathrm{~cm}$, and lengths for the salt treatments were between $3.77 \mathrm{~cm}$ and $8.79 \mathrm{~cm}$ (Table 4). Seedling lengths of the salt treatments were less than the control, and tended to decrease with an increase in salt concentration. Akbarimoghaddam et al. (2011) obtained similar results. Significant decreases in seedling length occurred due to a decreased in the osmotic potential. The 'Beyaziye' genotype was most susceptible to salt stress, with a $72 \%$ decrease in seedling length (compared to the control) at the highest concentration. Among all of the genotypes, the 'Bagacak' genotype was less affected by salt stress, with a $32 \%$ reduction in seedling length at the highest salt concentration, compared to the control.

Root fresh weight of the genotypes ranged from $24.94 \mathrm{~g}$ to $49.46 \mathrm{~g}$, and for salt concentration treatments were between $35.51 \mathrm{~g}$ and $46.64 \mathrm{~g}$ (Table 5). Compared to the control treatment, root fresh weight at $150 \mathrm{mM} \mathrm{NaCl}$ concentration was $62 \%$ higher for 'Sorgul' genotype and $47 \%$ higher for 'Altintoprak 98'. Alternatively, root fresh weight was significantly reduced for 'Line 286 ' and 'Line 299 ' in the presence of salt- induced stress. Shahzad et al. (2012) pointed out that root fresh weight decreases with increases in salt concentration, and can be used in selection for tolerance to salt-induced stress.

Root dry weights of the genotypes were between $3.94 \mathrm{mg}$ and $5.30 \mathrm{mg}$. The root dry weights for the salt treatments were between $3.64 \mathrm{mg}$ and $4.84 \mathrm{mg}$. As salt concentration increased, the reduction in root dry weight tended to decrease (Table 5). Reductions in root dry weight were related to root length responses. Varda et al. (2014) reported a reduction in durum wheat root dry weight with the increase in salt concentration. Although root dry weight of 'Beyaziye' genotype was the lowest among the studied genotypes, compared to the control, it had the highest root dry weight at $150 \mathrm{mM} \mathrm{NaCl}$, with a $7 \%$ increase compared to the control. Root dry weight for the 'Sorgul' genotype increased in the $50 \mathrm{mM}$ and $100 \mathrm{mM}$ salt concentrations, whereas root dry weight of 'Bagacak' and 'Line $299^{\prime}$ decreased substantially.

Seedling fresh weight of the genotypes ranged from $37.93 \mathrm{mg}$ to $59.42 \mathrm{mg}$, and treatment averages were between $32.38 \mathrm{mg}$ and $60.86 \mathrm{mg}$ (Table 6). Seedling fresh weight of the salt treatments was less than the control, which was also reported by Muhammad and Husaain (2012). The seedling fresh weights of 'Altintoprak 98' and 'DZT21' increased in $50 \mathrm{mM}$ and $100 \mathrm{mM}$ salt concentrations compared to the control. Seedling fresh weight of 'Beyaziye' was the highest among the genotypes for the control treatment, but fresh weight decreased by $62 \%$ in the 150 $\mathrm{mMNaCl}$ concentration.

Seedling dry weight of the genotypes was between $4.61 \mathrm{mg}$ and $7.50 \mathrm{mg}$ (Table 6). The treatment seedling dry weight averages were between $4.24 \mathrm{mg}$ and $7.33 \mathrm{mg}$. Seedling dry 
Table 6. Average value of seedling fresh weight $(\mathrm{mg})$ and seedling dry weight $(\mathrm{mg})$ of some durum wheat genotypes grown in different salt concentration

\begin{tabular}{|c|c|c|c|c|c|c|c|c|c|c|c|c|c|c|c|c|}
\hline \multirow{3}{*}{ Genotypes } & \multicolumn{10}{|c|}{ Seedling Fresh Weight (mg) } & \multicolumn{6}{|c|}{ Seedling Dry Weight (mg) } \\
\hline & \multicolumn{10}{|c|}{ Salt Concentration $(\mathrm{mM} \mathrm{NaCl})$} & \multicolumn{6}{|c|}{ Salt Concentration $(\mathrm{mM} \mathrm{NaCl})$} \\
\hline & \multicolumn{2}{|l|}{0} & \multicolumn{2}{|c|}{50} & \multicolumn{2}{|c|}{100} & \multicolumn{2}{|c|}{150} & \multicolumn{2}{|c|}{ Average } & 0 & 50 & 100 & 150 & Averag & \\
\hline 'Line 299' & 46.3 & $\mathrm{~g}-\mathrm{m}$ & 47.7 & $f-k$ & 37.2 & j-o & 21.2 & $\circ$ & 37.9 & d & 5.90 & 5.53 & 4.30 & 2.73 & 4.61 & f \\
\hline 'Line 286’' & 62.6 & $\mathrm{a-g}$ & 67.7 & a-e & 55.3 & $\mathrm{~d}-\mathrm{i}$ & 32.8 & k-o & 54.4 & $\mathrm{ab}$ & 7.67 & 7.90 & 8.00 & 4.20 & 6.97 & abc \\
\hline 'Altintoprak 98' & 40.8 & h-n & 46.8 & $f-1$ & 43.5 & h-n & 28.6 & no & 39.7 & d & 6.23 & 5.76 & 5.30 & 3.23 & 5.14 & def \\
\hline ‘6DZT21’ & 53.4 & $d-j$ & 55.5 & d-i & 55.1 & $d-i$ & 34.4 & k-o & 49.2 & bc & 6.20 & 6.93 & 5.30 & 4.60 & 5.76 & $c-f$ \\
\hline ‘6DZT29’ & 55.0 & $\mathrm{~d}-\mathrm{i}$ & 46.2 & $\mathrm{~g}-\mathrm{m}$ & 40.3 & $\mathrm{i}-\mathrm{n}$ & 29.2 & 1-o & 42.5 & $\mathrm{~cd}$ & 5.93 & 5.30 & 4.50 & 3.16 & 4.72 & ef \\
\hline 'Mersiniye' & 63.0 & $\mathrm{a-g}$ & 54.9 & $\mathrm{~d}-\mathrm{i}$ & 49.6 & $\mathrm{f}-\mathrm{k}$ & 28.9 & mno & 48.8 & bc & 7.70 & 7.10 & 6.50 & 3.93 & 6.30 & $a-d$ \\
\hline 'Menceki' & 74.7 & $\mathrm{abc}$ & 78.5 & a & 38.3 & i-o & 46.4 & $g-m$ & 59.4 & a & 9.10 & 9.93 & 5.10 & 5.90 & 7.50 & a \\
\hline 'Beyaziye' & 77.5 & ab & 57.7 & c-h & 50.5 & $e-k$ & 29.2 & $1-0$ & 53.7 & $\mathrm{ab}$ & 8.13 & 7.20 & 4.70 & 3.90 & 5.97 & b-e \\
\hline 'Sorgul' & 66.9 & $a-e$ & 64.2 & $a-f$ & 61.2 & b-g & 32.7 & $k-o$ & 56.2 & $\mathrm{ab}$ & 9.00 & 7.57 & 7.80 & 4.56 & 7.24 & $\mathrm{ab}$ \\
\hline 'Bagacak' & 68.4 & $a-d$ & 57.5 & $c-h$ & 67.4 & $a-e$ & 39.5 & $i-n$ & 58.2 & a & 7.37 & 5.40 & 7.70 & 6.16 & 6.65 & $\mathrm{abc}$ \\
\hline Mean & $60.9^{a}$ & & $57.7^{a}$ & & 49.3 & & $32.3^{c}$ & & & & $7.33^{a}$ & $6.86^{a}$ & $5.92^{b}$ & $4.24^{c}$ & & \\
\hline
\end{tabular}

Means followed by the same letter are not significantly different $(\mathrm{p}<0.05)$

Table 7. Average value of germination rate (\%) and seed vigor (\%) of some durum wheat genotypes grown in different salt concentration

\begin{tabular}{|c|c|c|c|c|c|c|c|c|c|c|}
\hline \multirow{3}{*}{ Genotypes } & \multicolumn{5}{|c|}{ Germination Rate (\%) } & \multicolumn{5}{|c|}{ Seed Vigor $(\%)$} \\
\hline & \multicolumn{5}{|c|}{ Salt Concentration $(\mathrm{mM} \mathrm{NaCl})$} & \multicolumn{5}{|c|}{ Salt Concentration $(\mathrm{mM} \mathrm{NaCl})$} \\
\hline & 0 & 50 & 100 & 150 & Average & 0 & 50 & 100 & 150 & Average \\
\hline 'Line 299' & $57.3^{a-d}$ & $49.3^{\mathrm{b}-\mathrm{g}}$ & $40.0^{c-j}$ & $13.3^{\mathrm{n}-\mathrm{q}}$ & $40.0^{\text {bcd }}$ & $76.0^{\mathrm{abc}}$ & $76.0^{\mathrm{abc}}$ & $59.0^{\text {b-e }}$ & $34.7^{g-j}$ & $61.3^{\mathrm{ab}}$ \\
\hline 'Line 286' & $53.3^{\mathrm{b}-\mathrm{f}}$ & $45.3^{\mathrm{b}-\mathrm{h}}$ & $33.3^{\mathrm{f}-\mathrm{n}}$ & $20.0^{j-q}$ & $38.0^{\mathrm{cd}}$ & $77.3^{\mathrm{ab}}$ & $73.3^{\mathrm{abc}}$ & $56.0^{\mathrm{c}-\mathrm{f}}$ & $34.7^{g-j}$ & $60.3^{\mathrm{ab}}$ \\
\hline 'Altintoprak 98' & $76.0^{\mathrm{a}}$ & $60.0^{\mathrm{abc}}$ & $37.3^{d-1}$ & $34.7^{\mathrm{e}-\mathrm{m}}$ & $52.0^{a}$ & $85.3^{\mathrm{a}}$ & $78.7^{\mathrm{ab}}$ & $52.0^{\mathrm{d}-\mathrm{g}}$ & $49.3^{\mathrm{d}-\mathrm{h}}$ & $66.3^{a}$ \\
\hline ‘6DZT21’ & $64.0^{\mathrm{ab}}$ & $54.7^{\mathrm{b}-\mathrm{e}}$ & $48.0^{\mathrm{b}-\mathrm{g}}$ & $22.7^{\mathrm{i}-\mathrm{q}}$ & $47.3^{\mathrm{ab}}$ & $74.7^{\mathrm{abc}}$ & $66.7^{\mathrm{a}-\mathrm{d}}$ & $52.0^{\mathrm{d}-\mathrm{g}}$ & $28.0^{\mathrm{i}-\mathrm{m}}$ & $55.3^{\mathrm{bc}}$ \\
\hline ‘6DZT29’ & $32.0^{\mathrm{g}-\mathrm{o}}$ & $30.7^{\text {g-o }}$ & $21.3^{j-q}$ & $4.0^{\mathrm{q}}$ & $22.0^{\mathrm{ef}}$ & $78.7^{\mathrm{ab}}$ & $62.7^{\text {b-e }}$ & $37.0^{f-j}$ & $13.3^{\mathrm{Im}}$ & $48.0^{\mathrm{cd}}$ \\
\hline 'Mersiniye' & $38.7^{\mathrm{d}-\mathrm{k}}$ & $40.0^{c-j}$ & $17.3^{1-q}$ & $4.0^{\mathrm{q}}$ & $25.0^{e}$ & $66.7^{\mathrm{a}-\mathrm{d}}$ & $65.3^{\mathrm{a}-\mathrm{d}}$ & $28.0^{\mathrm{i}-\mathrm{m}}$ & $12.0^{\mathrm{m}}$ & $43.0^{\mathrm{d}}$ \\
\hline 'Menceki' & $54.7^{\text {b-e }}$ & $42.7^{\mathrm{c}-\mathrm{i}}$ & $16.0^{\mathrm{m}-\mathrm{q}}$ & $25.3^{h-p}$ & $34.7^{d}$ & $77.3^{a b}$ & $60.0^{\mathrm{b}-\mathrm{e}}$ & $28.0^{\mathrm{i}-\mathrm{m}}$ & $45.3^{e-i}$ & $52.7^{b c}$ \\
\hline 'Beyaziye' & $26.7^{\text {h-p }}$ & $26.7^{\text {h-p }}$ & $18.7^{\mathrm{k}-\mathrm{q}}$ & $13.3^{\mathrm{n}-\mathrm{q}}$ & $21.3^{\text {ef }}$ & $32.0^{\mathrm{h}-\mathrm{I}}$ & $33.3^{g-k}$ & $27.0^{\mathrm{i}-\mathrm{m}}$ & $21.3^{\mathrm{j}-\mathrm{m}}$ & $28.3^{\mathrm{e}}$ \\
\hline 'Sorgul' & $64.0^{\mathrm{ab}}$ & $57.3^{a-d}$ & $48.0^{\mathrm{b}-\mathrm{g}}$ & $12.0^{\circ p q}$ & $45.3^{\mathrm{abc}}$ & $85.3^{a}$ & $72.0^{\mathrm{abc}}$ & $65.0^{\mathrm{a}-\mathrm{d}}$ & $36.0^{g-i}$ & $64.7^{\mathrm{a}}$ \\
\hline 'Bagacak' & $25.3^{\mathrm{h}-\mathrm{p}}$ & $13.3^{n-q}$ & $9.3^{\mathrm{pq}}$ & $10.0^{\mathrm{Pq}}$ & $14.5^{f}$ & $62.7^{\mathrm{b}-\mathrm{e}}$ & $25.3^{j-m}$ & $21.0^{j-m}$ & $14.0 \mathrm{klm}$ & $30.8^{e}$ \\
\hline Mean & $49.2^{\mathrm{a}}$ & $42.0^{b}$ & $28.9^{c}$ & $15.9^{d}$ & & $71.6^{\mathrm{a}}$ & $61.3^{b}$ & $42.5^{c}$ & $28.9^{d}$ & \\
\hline
\end{tabular}

Means followed by the same letter are not significantly different $(\mathrm{p}<0.05)$

weights of the salt treatments were less than for the control treatment. Compared to the control, 'Bagacak' was the least affected genotype, with a $16 \%$ seedling dry weight decrease when grown in the $150 \mathrm{mM} \mathrm{NaCl}$ concentration. 'Beyaziye' (52\%) and 'Line 299' (53\%) were the most affected genotypes in terms of reductions in seedling dry weight.

The germination rate of the genotypes was between 14.5\% and $52.0 \%$, and between $15.9 \%$ and $49.2 \%$ for the salt treatments. As anticipated, germination rates for the salt treatments were less than the control treatment. Similar findings were reported by Kara and Kara (2010), Kizilgeci et al. (2010) and Sung (1981). Sarin and Narayan (1968) identified the seed germination period as the time when salt stress has the greatest impact on plant growth and development. 'Altintoprak 98' had the highest germination $(6 \%)$ in the control treatment and the lowest were recorded for 'DZT29' and 'Mersiniye' (4\%).

Seedling vigour of the genotypes for the salt treatments was from $28.33 \%$ to $66.33 \%$. Seedling vigour of the salt treatments ranged from $28.86 \%$ to $71.60 \%$ (Table 7). 'Bagacak' had the lowest seedling vigour, whereas 'Altintoprak 98' and 'Menceki' had the highest vigour among the 10 genotypes. Seedling vigour significantly decreased with increasing salt concentration, which was also reported by Kizilgeci et al. (2010), Khan et al. (2005) and Sharma et al. (2004).

\section{Conclusions}

Both genotype and salt doses effects were significant for the studied parameters: coleoptile length, seedling length, root length, seedling fresh weight, root fresh weight, seedling dry weight, root dry weight, germination rate and seedling vigor. For these parameters, there were also significant reductions with increasing salt concentration. For coleoptile length, seedling fresh weight, germination rate and seedling vigour, 'Altintoprak 98' was the most salt tolerant genotype. Within the context of root length and root dry weight, 'Sorgul' was most tolerant of salinity stress. Seedling length, germination rate and seed vigor showed the greatest potential as selectable parameters to increase salt tolerance. As confirmation of these laboratory results, follow-up field testing is recommended.

\section{References}

Ahmad MSA, Ali Q, Bashir R, Javed F, Alvi AK (2006). Time course changes in ionic composition and total soluble carbohydrates in two barley cultivars at seedling stage under salt stress. Pakistan Journal of Botany 38(5):1457-1466.

Akbari G, Sanavy SAMM, Yousafzadeh S (2007). Effect of auxin and salt stress $(\mathrm{NaCl})$ on seed germination of wheat cultivars (Triticum aestivum L). Pakistan Journal of Biological Sciences 10(15):25572561.

Akbarimoghaddam H, Galavi M, Ghanbari A, Panjehkeh N (2011). Salinity effects on seed germination and seedling growth of bread wheat cultivars. Trakia Journal of Sciences 9(1):43-50.

Atak M, Kaya MD, Kaya G, Çakll Y, Çiftçi CY (2006). Effects of $\mathrm{NaCl}$ on the germination, seedling growth and water uptake of triticale. Turkish Journal of Agriculture and Foresty 30:39-47.

Dinç U, Şenol S, Kapur S, Atalay I, Cangir C (1993). Turkish Soils. 
112

Agricultural Faculty of Cukurova University, No 51. Lecturer book No 12, Adana.

Ekmekçi E, Apan M, Kara T (2005). The effects of salt to plant growth. Journal of Agricultural Faculty of Ondokuz Mayis University 20(3):188-125.

El-Hendawy SE, Hu Y, Yakout GM, Awad AM, Hafiz SE, Schmidhalter U (2005). Evaluating salt tolerance of wheat genotypes using multiple parameters. European Journal of Agronomy 22:243-253.

FAO (2008). Food and agriculture organization of the United Nations, Rome (www.fao.org).

FAO (2013). Food and agriculture organization of the United Nations, Rome (www.fao.org).

Francois LE, Mass EV, Donovan TJ, Youngs VL (1986). Effect of salinity on grain yield and quality, vegetative growth and germination of semi-dwarf bread wheat and durum wheat. Agronomy Journal 78(6):1053-1058.

Kanber R, Ünlü M (2010). Water and soil saltiness in agriculture. Agricultural Faculty of Cukurova University, No 281. Lecturer book No A-87, Adana.

Kara B, Kara NU (2010). Effect of different salinity $(\mathrm{NaCl})$ concetrations of the first developmet stages of root ad shoot organs of wheat. Anadolu Journal of Agricultural Sciences 25(1):37-43.

Khan BA, Khan AN, Khan TH (2005). Effect of salinity on the germination of fourteen wheat cultivars. Gomal University Journal of Research 21:31-33.

Kizilgeci F, Yildirim M, Akinci C (2010). Determination of salinity reactions of some bread wheat (Triticum aestivum L.) genotypes. 1 . Symposium of Udusis, 24-26 May 2010, Diyarbakir, pp 301-307.

Kumar P, Kumar A, Masis SN, Shamshory AP (1981). Tolerance of barley varieties to salt stress at seedling stage. Indian Journal of Plant Physiology 24(4):304-311.
Mass EV, Poss JA (1989). Salt sensitivity of wheat at various growth stages. Irrigation Science 10:2940.

Muhammad Z, Hussain F (2012). Effect of $\mathrm{NaCl}$ salinity on the germination and seedling growth of seven wheat genotypes. Pakistan Journal of Botany 44(6):1845-1850.

Munns R, James RA, Lauchli A (2006). Approaches to increasing the salt tolerance of wheat and other cereals. Journal of Experimental Botany 57:1025-1043.

Parida AK, Das AB (2005). Salt tolerance and salinity effect on plants: a review. Ecotoxicology and Environmental Safety 60:324-349.

Saboora A, Kriarostami K (2006). Salinity $(\mathrm{NaCl})$ tolerance of wheat genotypes at germination and early seedling growth. Pakistan Journal of Biological Science 9(11):2009-2021.

Sarin MN, Narayanan A (1968). Effects of soil salinity and growth regulators on germination and seedling metabolism of wheat. Physiologia Plantarum 21:1201-1209.

Shahzad A, Ahmad M, Iqbal M, Ahmed I, Ali GM (2012). Evaluation of wheat landrace genotypes for salinity tolerance at vegetative stage by using morphological and molecular markers. Genetics and Molecular Research 11(1):679-692.

Sharma AD, Thakur M, Rana M, Singh K (2004). Effect of plant growth hormones and abiotic stresses on germination, growth and phosphatase activities in Sorghum bicolour (L.) moench seeds. African Journal of Biotechnology 3:308-312.

Sung JM (1981). Effects of sodium chloride $(\mathrm{NaCl})$ salinity and germination of barley cultivars. Journal of the Agricultural Association of China 113:41-47.

Vardar Y, Çifci EA, Yağdi K (2014). Salinity effects on germination stage of bread and durum wheat cultivars. Yuzuncu Yil University Journal of Agricultural Sciences 24(2):127-139. 